\title{
Prostaglandin F-2 $\alpha$ receptors in corpora lutea of pregnant rats and relationship with induction of $20 \alpha$-hydroxysteroid dehydrogenase
}

\author{
L. E. Bussmann* \\ Laboratorio de Reproduccion y Lactancia (LARLAC), CRICYTME, Mendoza, Argentina
}

\begin{abstract}
Summary. Luteal receptors for PGF-2 $\alpha$ in the pregnant rat were characterized. No changes in the $K_{\mathrm{d}}$ were found during pregnancy, whereas capacity increased to a maximum on Day 19, decreasing thereafter. The decrease in binding sites seen from Days 20 to 22 may be due to down regulation of the receptor by its ligand, since it was prevented by inhibition of PG synthesis by indomethacin treatment. Likewise, in-vivo treatment with PGF- $2 \alpha$ reduced the apparent number of PG binding sites.

$P G$ receptor concentration seems to be modulated by oestrogens since an increment was found on Day 19, associated with the known increase in plasma oestradiol concentrations, and since receptor concentration on Day 16 was significantly increased by oestradiol benzoate.

The uterus also had a negative influence on the appearance of the PG receptor, since hysterectomy on Day 16 increased the number of binding sites on Day 18 . However, receptor concentration and $20 \alpha$-hydroxysteroid dehydrogenase induction by hysterectomy was not affected by indomethacin, indicating that these events are probably not related to prostaglandin withdrawal. However, treatment with hCG, which diminishes enzyme induction by hysterectomy, did not produce changes in receptor concentration.

The present results suggest that PGF-2 $\alpha$, acting through a specific receptor site, is the physiological luteolytic signal. The consequence of its receptor binding seems to be the blockade of a gonadotrophic stimulus, which in turn determines (1) the decrease in progesterone synthesis and (2) the induction of $20 \alpha$-hydroxysteroid dehydrogenase.
\end{abstract}

Keywords: PFG-2 $\alpha$; receptors; rat; CL; 20a-hydroxysteroid dehydrogenase

\section{Introduction}

A decrease in circulating progesterone concentrations must precede the initiation of parturition. At that time, corpus luteum regression occurs in spite of the presence of luteotrophic signals, such as placental lactogen and a luteotrophin with an hCG-like activity (Shiu et al., 1973; Blank et al., 1979). Therefore, a luteolytic signal must override those gonadotrophic stimuli. At the end of pregnancy, the induction of luteal $20 \alpha$-hydroxysteroid dehydrogenase (20 $\alpha$-HSD, EC 1.1.1.149) is a sign of functional luteolysis and is responsible for the sharp decrease in circulating progesterone values that precedes parturition (Wiest et al., 1968; Kuhn \& Briley, 1970).

The luteolytic action of prostaglandin (PG) F-2 $\alpha$ in the rat was first demonstrated by Pharriss \&

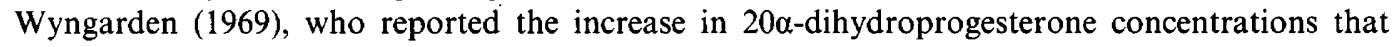
follow PG treatment. Subsequently, several hypotheses were proposed for the mechanism of action

*Present address: Instituto de Biología y Medicina Experimental, Vuelta de Obligado 2490, 1428 Buenos Aires, Argentina. 
of PGF-2 $\alpha$ (reviewed in Behrman et al., 1979). Specific receptors for PGF-2 $\alpha$ have been described for corpora lutea (CL) of cows (Rao, 1975) and of cyclic and pseudopregnant rats (Wright et al., 1979, 1980; Muller et al., 1981). A physiological role of this PG at the end of pregnancy is indicated by the prevention of the normal induction of $20 \alpha-H S D$ activity that is caused by indomethacin, an inhibitor of prostaglandin synthesis (Strauss \& Stambaugh, 1974).

The rapid induction of $20 \alpha$-HSD activity after PGF- $2 \alpha$ treatment suggests an effect of the PGF$2 \alpha$ on the synthesis of this enzyme (Bussmann \& Deis, 1979). This is also indicated by the abolition to a different extent by indomethacin of the inductions of enzyme activity caused either in early pregnancy with 2-bromo- $\alpha$-ergocriptine or in late pregnancy with aminoglutethimide or hCG (Hickman-Smith \& Kuhn, 1976).

The experiments reported here were undertaken to study the participation of the PG receptor in the mechanism of luteolysis and $20 \alpha$-HSD induction in late pregnancy.

\section{Materials and Methods}

All chemicals were reagent grade obtained from Sigma Chemical Co. (St Louis, MO, USA) unless otherwise indicated. $\left[5,6,8,9,11,12,14,15-{ }^{3} \mathrm{H}\right]$ Prostaglandin F-2 $\alpha$ (sp. act. $\left.150 \mathrm{Ci} / \mathrm{mmol}\right)$ and $\left[1,2,6,7-{ }^{3} \mathrm{H}\right]$ progesterone (sp. act. $90 \mathrm{Ci} / \mathrm{mmol}$ ) were from New England Nuclear Corp. (Boston, MA, USA). Acetonitrile was from Merck (Darmstadt, West Germany) and Silastic tubing from Ducilo Argentina (Buenos Aires, Argentina). The following were generously donated: indomethacin phosphate (Montpellier Argentina, Buenos Aires, Argentina), PGF-2 $\alpha$-Tris salt (the Upjohn Company, Buenos Aires, Argentina), 2-bromo- $\alpha$-ergocriptine mesylate (Sandoz, Buenos Aires, Argentina), ovine prolactin NIH-S-11 (NIADDK, Baltimore, MD, USA).

Animals and general methodology. White nulliparous rats, about 3 months old $(180-200 \mathrm{~g})$ were used. They were caged with a male rat during the night after pro-oestrus. The next morning was taken as Day 1 of pregnancy if spermatozoa were found in the vaginal smear. In our colony, rats usually deliver on Day 23 . The rats were kept in a constant-temperature room $\left(24 \pm 2^{\circ} \mathrm{C}\right.$ ) with a controlled light cycle (lights on from 06:00 to 20:00 h).

Hysterectomies were performed, under light ether anaesthesia, through a ventral incision; sham-operated animals received only the incision. The rats were killed by decapitation; blood was collected, allowed to clot and centrifuged. Serum was kept frozen at $-30^{\circ} \mathrm{C}$ until assayed.

Ovaries were collected immediately after killing the rats and put in ice-cold saline $(9 \mathrm{~g} \mathrm{NaCl} / 1)$ containing indomethacin phosphate $(10 \mu \mathrm{g} / \mathrm{ml})$. The $\mathrm{CL}$ were dissected under a stereoscopic microscope by means of small forceps and a needle; they were counted and weighed before homogenization with an Ultra-Turrax in $3 \mathrm{ml}$ ice-cold buffer (10 mM-Tris, $250 \mathrm{~mm}$-sucrose, $1 \mathrm{~mm}-\mathrm{CaCl}_{2}, 1 \mathrm{~mm}$-dithiothreitol, $0.1 \% \mathrm{BSA}, 0.1 \% \mathrm{Na}_{3} \mathrm{~N}, 2 \mathrm{~nm}$-indomethacin phosphate) $\mathrm{pH} 7.0$ (TIS buffer) and centrifuged at $800 \mathrm{~g}$ for $10 \mathrm{~min}$. The supernatant was centrifuged again at $20000 \mathrm{~g}$ for $45 \mathrm{~min}$. The supernatant was saved for $20 \alpha$-HSD determination in some cases. The pellet was resuspended in TIS buffer in a proportion of $20 \mu \mathrm{l}$ per $3 \mathrm{mg}$ original tissue.

Protein determinations were performed, after digestion of an aliquant of membrane with $1 \mathrm{~N}-\mathrm{NaOH}$, by the method of Lowry et al. (1951) using bovine serum albumin as standard.

PGF-2a receptor assay. PGF- $2 \alpha$ receptors were assessed as described by Wright $e t$ al. (1979), with minor modifications. Duplicate $20 \mu \mathrm{l}$ samples of luteal membrane preparation (160-220 $\mu \mathrm{g}$ protein) were incubated with different concentrations of the tracer $(1-80 \mathrm{nM})$, in a final volume of $50 \mu \mathrm{l}$ in plastic tubes. Incubation was stopped by placing the samples in an ice bath and adding $1 \mathrm{ml}$ TBSA buffer ( $10 \mathrm{~mm}$-Tris, $1 \mathrm{~mm}-\mathrm{CaCl}_{2}, 1 \mathrm{~mm}$-dithiothreitol, $0.1 \% \mathrm{BSA}$, $\left.0.1 \% \mathrm{Na}_{3} \mathrm{~N}\right) \mathrm{pH} 7.0$ and $1 \mathrm{mg}$ celite. Membrane-bound $\left[{ }^{3} \mathrm{H}\right] \mathrm{PGF}-2 \alpha$ was separated by centrifugation at $6000 \mathrm{~g}$ for $30 \mathrm{~min}$, washed once with $1 \mathrm{ml}$ TBSA buffer, centrifuged again, and the pellet resuspended in $1 \mathrm{ml}$ TBSA buffer. This was then transferred to a scintillation vial and counted in a Kontron 300 DPM (Kontron AG, Switzerland) with automatic quench correction using Bray's scintillation cocktail. Non-specific binding was assessed in each experiment, and for each $\left.{ }^{3} \mathrm{H}\right]$ PGF-2 $\alpha$ concentration, by incubating aliquants in duplicate with an excess of unlabelled PGF-2 $\alpha$ $(1 \mu \mathrm{M})$. The quantity of $\left[{ }^{3} \mathrm{H}\right] \mathrm{PGF}-2 \alpha$ bound in these samples $(0.4 \%)$ was essentially the same as that in tubes in which there were no luteal membranes. The non-specific binding was subtracted from total binding to obtain specific binding.

The purity of the $\left[{ }^{3} \mathrm{H}\right] \mathrm{PGF}-2 \alpha$ was routinely checked by thin-layer chromatography on silica gel $\mathrm{G}$ using tolueneethyl acetate-methanol-acetic acid (20:80:3:3, by vol.). When purity was $<95 \%$, the tracer was repurified before use in binding studies. Also, in the studies of association kinetics, after the incubations for the different times and temperatures the purity of the tracer was checked. Membrane-bound and free $\left[{ }^{3} \mathrm{H}\right] \mathrm{PG}$ were separated by centrifugation and both fractions were acidified, extracted with ethyl acetate and chromatographed in the system described above.

Studies on the temperature dependence of binding were performed using a pool of CL from 20-day-pregnant rats. Aliquants were incubated at different temperatures in the presence of $7 \mathrm{nM}-\left[{ }^{3} \mathrm{H}\right] \mathrm{PGF}-2 \alpha$ alone or plus $1 \mu \mathrm{M}$ unlabelled PGF-2 $\alpha$. At different times the incubation was stopped and processed as above. Dissociation analyses were done on a pool of CL from 20-day-pregnant rats, preincubated with $6 \mathrm{nM}-\left[{ }^{3} \mathrm{H}\right] \mathrm{PGF}-2 \alpha$ for $90 \mathrm{~min}$ at $30^{\circ} \mathrm{C}$. At zero time $1 \mathrm{nmol}$ 
unlabelled PGF- $2 \alpha$ in $1 \mathrm{ml}$ TIS buffer was added and the incubation was allowed to proceed for various times. Association $\left(K_{\mathrm{a}}\right)$ and dissociation $\left(K_{\mathrm{d}}\right)$ rate constants were assessed as described by Schrader (1975).

Saturation analysis was performed, using membrane preparations from 3 rats at the same stage of pregnancy, for each day studied. Samples were incubated with $9\left[{ }^{3} \mathrm{H}\right] \mathrm{PGF}-2 \alpha$ concentrations ranging from 1 to $80 \mathrm{nM}$. Scatchard plots (Scatchard, 1949) were used to determine equilibrium constants $(K)$. PGF- $2 \alpha$ receptor concentrations for the different days of pregnancy, which are shown in Fig. 2, were determined in luteal membranes from single rats (i.e. without pooling). Incubation with the tracer was done at 3 concentrations, 5,20 and $80 \mathrm{~nm}$.

20a-HSD and hormone assays. Luteal 20a-HSD enzymic activity was determined in a computerized model 101 Hitachi spectrophotometer (Hitachi Ltd, Tokyo, Japan) as previously described (Bussmann \& Deis, 1979). The supernatant from the $20000 \mathrm{~g}, 45 \mathrm{~min}$ centrifugation $(50-500 \mu \mathrm{l})$ was preincubated at $37^{\circ} \mathrm{C}$ for $10 \mathrm{~min}$ in a 1 -ml cuvette with $0.35 \mu \mathrm{mol} \mathrm{NADP}{ }^{+}$in a final volume of $975 \mu \mathrm{l}$. The reaction was started by the addition of $0 \cdot 1 \mu \mathrm{mol} 20 \alpha$-dihydroprogesterone in $25 \mu \mathrm{l}$ ethanol. Change in extinction at $340 \mathrm{~nm}$ was recorded for $5 \mathrm{~min}$. Enzyme activities are expressed in $\mathrm{mU}$, one $\mathrm{U}$ being equal to the formation of $1 \mu \mathrm{mol} \mathrm{NADPH} / \mathrm{min}$ at $37^{\circ} \mathrm{C}$.

Serum progesterone concentrations were assessed by radioimmunoassay and placental lactogen by a radioreceptor assay as described previously (Bussmann \& Deis, 1979). All serum samples were measured in a single assay to eliminate interassay variations. The limit of sensitivity of the progesterone assay was $12.5 \mathrm{pg}$ (per tube) and the mean intra-assay coefficient of variation was $6.5 \%$.

Placental lactogen was determined using a membrane preparation from livers of female rats. The tracer used was ${ }^{125}$ I-labelled oPRL (NIH-oPRL S12, $35 \mathrm{IU} / \mathrm{mg}$ ) iodinated by the lactoperoxidase method (Thorell \& Johansson, 1971). The same prolactin tracer was used for the standard curve, and serum of males was added in the same proportion that was present in the sample tubes. The sensitivity of the assay ranged from 0.4 to $50 \mathrm{ng} / \mathrm{tube}$. Mean intraassay coefficient of variation was $9 \%$.

Intraluteal steroid concentrations were determined by h.p.l.c. using Waters equipment with a $\mu$ Bondapack column C18 (Rodriguez-Consword, Bernal, Buenos Aires, Argentina) and acetonitrile:water $(50: 50 \mathrm{v} / \mathrm{v})$ as the mobile phase. Steroids were detected at $254 \mathrm{~mm}$. The lowest detectable concentrations of progesterone and $20 \mathrm{a}$-dihydroprogesterone were $2 \mathrm{ng}$. Both ovaries were removed, trimmed of surrounding fat and homogenized in $0.5 \mathrm{ml}$ buffer containing $50 \mathrm{~mm}$-sodium phosphate, $150 \mathrm{~mm}-\mathrm{NaCl}, 1 \mathrm{~mm}$-EDTA, $0.1 \%$ gelatin, $\mathrm{pH} \mathrm{7.4}$, and 10000 c.p.m. $\left[{ }^{3} \mathrm{H}\right]$ progesterone as internal standard. The homogenate was extracted twice with $2 \mathrm{ml}$ ethyl acetate and the combined organic phases were filtered through a Millipore filter FHLP $13 \mathrm{~mm}$ (MTN, Buenos Aires, Argentina) and dried under nitrogen. The residue was dissolved in acetonitrile and portions were used for h.p.l.c. analysis. The recovery was estimated by counting the $\left[{ }^{3} \mathrm{H}\right]$ progesterone in a liquid scintillation counter.

Statistical analysis. Results are given as means \pm s.e.m., with the number of observations in parentheses. Differences between groups were assessed by Student's $t$ test or Duncan's test for multiple comparisons.

\section{Results}

\section{Characterization of the prostaglandin receptor in corpora lutea of pregnancy}

The characterization of the PGF- $2 \alpha$ receptor was performed on luteal membrane preparations from Day 20 of pregnancy. As shown in Fig. 1(a) the association kinetics of $\left[{ }^{3} \mathrm{H}\right] \mathrm{PGF}-2 \alpha$ to luteal membranes were temperature dependent. At $37^{\circ} \mathrm{C}$ association was fast, reaching a maximum of $45 \mathrm{~min}$, and declining thereafter. As metabolism or degradation of the tracer was not found after incubation $\left(94 \cdot 7 \%, 94 \%\right.$ and $92 \%$ of the radioactivity was recovered as $\left[{ }^{3} \mathrm{H}\right] \mathrm{PG}$ after incubation for 60,90 and $120 \mathrm{~min}$, respectively), this decline is interpreted as an increase in dissociation or receptor degradation. The binding at $30^{\circ} \mathrm{C}$ was complete by $90 \mathrm{~min}$. At $24^{\circ} \mathrm{C}$ the binding was less rapid and increased throughout the time studied, without reaching the plateau. When the values were fitted to a hyperbolic function a time of $11.3 \mathrm{~h}$ was obtained to reach $95 \%$ of the $\mathrm{B}_{\max }$ at $24^{\circ} \mathrm{C}$. Very little binding was found when the incubation was performed at $0^{\circ} \mathrm{C}$. The $K_{\mathrm{a}}$ values $\left(\mathrm{M}^{-1} \mathrm{sec}^{-1}\right)$ were $1.18 \times 10^{5}, 1.09 \times 10^{5}, 3.39 \times 10^{4}$ and $1.82 \times 10^{3}$ at $37,30,24$ and $0^{\circ} \mathrm{C}$, respectively.

The dissociation of PGF- $2 \alpha$ at $30^{\circ} \mathrm{C}$ was rapid, so that by $15 \mathrm{~min}$ only $50 \%$ of the tracer was still bound, yielding a $K_{\mathrm{d}}$ of $2.06 \times 10^{-4} \mathrm{M} \mathrm{sec}^{-1}$ (Fig. 1b). The dissociation at $0^{\circ} \mathrm{C}$ was very slow. The equilibrium constant $\left(K_{\mathrm{d}}\right)$ at $30^{\circ} \mathrm{C}$, calculated as the ratio $K_{\mathrm{d}} / K_{\mathrm{a}}$, was $1.89 \times 10^{-9} \mathrm{M}$. In view of the above results the $90-\mathrm{min}$ period and the $30^{\circ} \mathrm{C}$ temperature were chosen for all incubations at equilibrium.

Figure 1(c) shows the saturation curve for PGF-2 $\alpha$ with various concentrations of the tracer. Saturation was reached at $80 \mathrm{nM}$. Scatchard analysis (Fig. 1c, insert) indicated a single binding site 
(a)

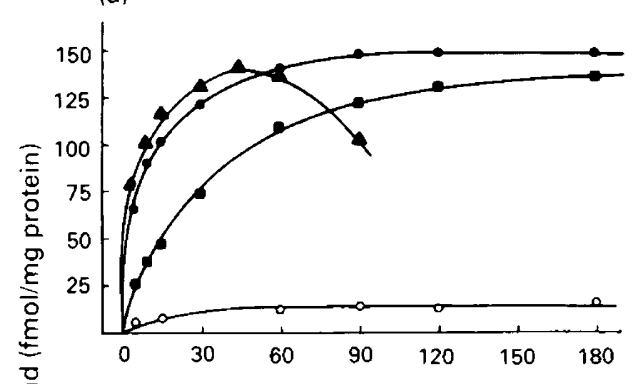

(c)

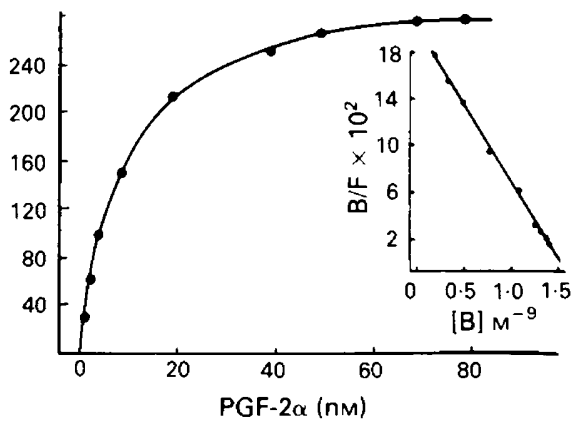

Fig. 1. Binding kinetics of the PGF-2 $\alpha$ receptor in CL of pregnant rats. (a) Association kinetics of PGF- $2 \alpha$ with luteal membrane binding sites. Membranes were incubated with $7 \mathrm{nM}$ $\left[{ }^{3} \mathrm{H}\right] \mathrm{PGF}-2 \alpha$ at $37^{\circ} \mathrm{C}(\boldsymbol{\Delta}), 30^{\circ} \mathrm{C}(\boldsymbol{O}), 24^{\circ} \mathrm{C}(\boldsymbol{\square})$ and $0^{\circ} \mathrm{C}(\mathrm{O})$. (b) Dissociation kinetics of PGF$2 \alpha$. Luteal membranes were labelled with $6 \mathrm{nM}-\left[{ }^{3} \mathrm{H}\right] \mathrm{PGF}-2 \alpha$ for $90 \mathrm{~min}$ at $30^{\circ} \mathrm{C}$, at zero time $1 \mathrm{ml}$ Buffer TIS containing $1 \mathrm{nmol}$ unlabelled PGF- $2 \alpha$ was added and the incubation allowed to proceed for different times at $30^{\circ} \mathrm{C}(O)$ and $0^{\circ} \mathrm{C}(O)$. (c) Saturation curve of PGF-2 $\alpha$ receptors. Luteal membranes were incubated for $90 \mathrm{~min}$ at $30^{\circ} \mathrm{C}$. Insert shows Scatchard plot of $\left[{ }^{3} \mathrm{H}\right] \mathrm{PGF}-2 \alpha$ binding data. For more details see text.

with high affinity and low capacity $\left(K_{\mathrm{d}} 7 \cdot 27 \pm 0.4 \times 10^{-9} \mathrm{M}, \mathrm{B}_{\max } 236 \pm 19 \mathrm{fmol} / \mathrm{mg}\right.$ protein, $\mathrm{N}=3)$. Almost identical affinities were found for pooled CL from different stages of pregnancy $\left(K_{\mathrm{d}}\right.$ range $7.68 \times 10^{-9}$ to $\left.5.83 \times 10^{-9} \mathrm{M}\right)$. The binding capacity on the different days ranged between 170 and $280 \mathrm{fmol} / \mathrm{mg}$ protein.

Specificity of the PGF-2 $\alpha$ receptor was tested against PGF-2 $\alpha$, cloprostenol (a PGF-2 $\alpha$ analogue), PGE-2, hCG and prolactin (data not shown). Only PGF-2 $\alpha$ and cloprostenol competed with $\left[{ }^{3} \mathrm{H}\right] \mathrm{PGF}-2 \alpha$ in almost a 1:1 ratio. Little competition was found with PGE-2. Prolactin and hCG, which are known to have specific receptors in luteal membranes, did not compete with the binding of the tracer.

\section{Changes in PGF-2a receptor concentrations during pregnancy}

The binding of PGF-2 $\alpha$ to luteal membranes was studied on Days 14, 16, 18, 19, 20, 21 and 22 of pregnancy (Fig. 2). The levels of specific binding rose significantly on Day 19 of pregnancy, when compared with Days 14, 16 and 18. On Day 20 the binding was still significantly high, but it decreased on Day 21 to the initial levels. Some increase was seen on Day 22 of pregnancy, but the values were still similar to those of Days 16 and 18 of pregnancy.

To determine whether the decrease in binding of PGF- $2 \alpha$ that is seen on Days 21 and 22 was due to down regulation of the receptor by endogenous prostaglandin, the binding was measured in pregnant rats that were previously treated with indomethacin. Figure 2 shows that indomethacin did not affect the amount of receptor on Days 14, 16, 18 and 19. However, indomethacin effectively prevented the decline in PGF-2 $\alpha$ binding that was seen in untreated rats on Days 20, 21 and 22, 


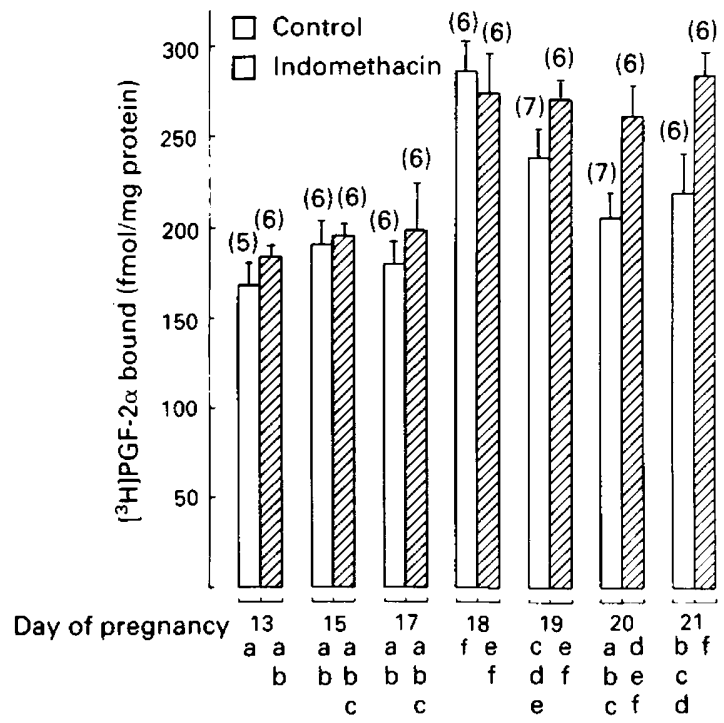

Fig. 2. PGF-2 $\alpha$ binding to luteal membranes of rats at different stages of pregnancy. Membranes were incubated for $90 \mathrm{~min}$ at $30^{\circ} \mathrm{C}$ with 5,20 and $80 \mathrm{nM}-\left[{ }^{3} \mathrm{H}\right] \mathrm{PGF}-2 \alpha$. Indomethacin (1 mg s.c.) was administered at 08:00, 20:00 and 08:00 h, starting the day before measurement. All rats were killed at $12: 00 \mathrm{~h}$. Values are means \pm s.e.m. for the no. of observations in parentheses. Bars with the same letter(s) are not significantly different at $P<0.05$.

leaving the receptor value on Days 19-22 significantly elevated over that on Days 14-18 of pregnancy. $K_{\mathrm{d}}$ values, measured on pooled preparations of ovaries from 3 rats, were unchanged.

\section{$P G F-2$ a receptor concentration after treatment in vivo with $P G F-2 a$}

To study further the down regulation of PGF-2 $\alpha$ receptor by its own ligand, 19-day-pregnant rats (6 rats each group), pretreated with indomethacin ( $1 \mathrm{mg}$ s.c. every $12 \mathrm{~h}$ starting the day before experiment at 08:00 h) were injected with PGF- $2 \alpha(750 \mu \mathrm{g}$ s.c.) or vehicle. Rats were killed $2 \mathrm{~h}$ or $24 \mathrm{~h}$ after treatment and the receptors measured. The $K$ values were determined in pooled preparations and no differences from the control group were found (data not shown). The receptor concentrations were significantly lower in both groups: PGF-2 $\alpha$ treatment $2 \mathrm{~h}$ before killing gave values of $215 \pm 23$ and $277 \pm 21 \mathrm{fmol} / \mathrm{mg}$ protein for treated controls $(P<0.01)$ and treatment PGF- $2 \alpha 24 \mathrm{~h}$ before killing gave values of $193 \pm 12$ and $272 \pm 10 \mathrm{fmol} / \mathrm{mg}$ protein in treated and controls $(P<0.001)$.

\section{Regulation of PGF-2a receptor by ovarian steroids and its relationship with the sensitivity for luteolysis}

Since the sensitivity of CL to the luteolytic action of PGF-2 $\alpha$ increases with their age, accompanying a decrease in serum progesterone and an increase in serum oestrogen concentrations, the participation of both steroids on the concentration of PGF- $2 \alpha$ receptor was studied. Progesterone was injected s.c. (10 mg in oil) every $12 \mathrm{~h}$ on Days $16,17,18$ and 19 , and the rats killed on Day 19 at $12: 00 \mathrm{~h}$, or implanted s.c. on the back with a progesterone-filled Silastic tubing ( $40 \mathrm{~mm}$ long $\times 3.2 \mathrm{~mm}$ i.d.) on Day 17, and the rats killed on Day 20 of pregnancy at 12:00 h. None of these treatments produced a significant change in the concentration (mean \pm s.e.m., 6 rats) of PGF- $2 \alpha$ binding sites: $270 \pm 10$ and $287 \pm 17 \mathrm{fmol} / \mathrm{mg}$ protein for progesterone-injected rats and oil-injected controls, respectively, and $220 \pm 10$ and $240 \pm 15 \mathrm{fmol} / \mathrm{mg}$ protein for progesteroneimplanted and empty-implant rats, respectively. 
Oestrogen treatment (oestradiol benzoate, $10 \mu \mathrm{g}$ in oil s.c.) was given on Days 14 and 15 of pregnancy at $08: 00 \mathrm{~h}$, and the rats (6 per group) were killed on Day 16 at 12:00 h, when the luteal receptor concentration in untreated rats in previous experiments was still low (see Fig. 2). This treatment caused a significant increase in receptor concentration, which was not different from that observed on Day $19(210 \pm 8$ and $191 \pm 13 \mathrm{fmol} / \mathrm{mg}$ protein in oestradiol-treated and oil-injected rats, respectively; $P<0.001$ ). In 6 additional rats, this treatment did not alter serum concentrations of progesterone (oestrogen-treated: $62.5 \pm 4.8 \mathrm{ng} / \mathrm{ml}$; oil-injected controls: $58.6 \pm$ $6.5 \mathrm{ng} / \mathrm{ml}$ ), or placental lactogen (oestrogen-treated: $975 \pm 96 \mathrm{ng} / \mathrm{ml}$; oil-injected controls: $1020 \pm 105 \mathrm{ng} / \mathrm{ml}$ ), suggesting that the placental support of luteal function was unaffected.

To find out whether this oestrogen-induced increase in PG binding sites has a physiological meaning, the sensitivity to PGF-2 $\alpha$ was studied in rats treated with oestradiol benzoate $(10 \mu \mathrm{g}$ in oil s.c.). On Day 16, when in the previous experiment an increase of PGF-2 $\alpha$ receptor to levels similar to those of Days 19-22 was seen, they were also treated with $750 \mu \mathrm{g}$ PGF- $2 \alpha$ s.c. The rats were killed $24 \mathrm{~h}$ later and $20 \alpha$-HSD activity was measured. The enzyme activity was not detectable in control rats and treatment with oestrogen alone did not produce a large increase $(9 \cdot 44 \pm 1 \cdot 1 \mathrm{mU} /$ $\min / 2$ ovaries, $\mathrm{N}=5$ ). Treatment with PGF-2 $\alpha$ on Day 16 , however, was followed by a larger increase in $20 \alpha-\mathrm{HSD}$ activity $24 \mathrm{~h}$ later $(53.76 \pm 5.6 \mathrm{mU} / \mathrm{min} / 2$ ovaries, $\mathrm{N}=7, P<0.001$ when compared with the previous value). When PGF-2 $\alpha$ was administered to oestrogen-pretreated rats, i.e. with higher levels of PGF-2 $\alpha$ receptor, the induction was found to be significantly greater $(175 \pm 21 \cdot 1 \mathrm{mU} / \mathrm{min} / 2$ ovaries, $\mathrm{N}=7, P<0.001)$ when compared with the group treated with PGF-2 $\alpha$ alone.

\section{Progesterone and 20a-HSD in control and indomethacin-treated pregnant rats (Fig. 3)}

Serum progesterone concentrations in control pregnant rats were generally high, although with a marked decrease on the last days of pregnancy. Luteal $20 \alpha$-HSD activity in the same rats was not detectable until Day 19 of pregnancy, but increased sharply on Day 22 . Indomethacin treatment completely prevented the fall of progesterone concentrations at the end of pregnancy, and markedly diminished the simultaneous induction of $20 \alpha-H S D$ activity. Moreover, none of a group of 6 rats that were treated with indomethacin from Day 21 until the morning of Day 24 had delivered by that night (when they were killed; data not shown in Fig. 3).

\section{Ovarian steroid concentration after PGF-2a treatment}

As shown in Table 1, at $2 \mathrm{~h}$ after treatment there was a decrease in both $20 \alpha$-dihydroprogesterone and progesterone concentrations, although the ratios of these steroids were similar to those of the control rats.

By $3 \mathrm{~h}$ after treatment, progesterone had further decreased in luteal cells, but $20 \alpha$-dihydroprogesterone started to increase, when compared with the $2 \mathrm{~h}$ concentration, reaching the control values. The total luteal progestagen remained essentially constant and so the $20 \alpha$-dihydroprogesterone/progesterone ratio changed dramatically.

This result seems to show that the first action of PGF- $2 \alpha$ on luteal steroidogenesis is the decrease of $\Delta^{4}-3$ oxo-steroid production, while the induction of $20 \alpha$-HSD activity could be either a consequence of this decrease or at least a later effect of the PGF- $2 \alpha$ on the luteal cell.

\section{Induction of 20a-HSD activity by hysterectomy}

To study whether the induction of $20 \alpha$-HSD in hysterectomized pregnant rats is a PG receptormediated response, both receptor concentration and enzymic activities were measured after hysterectomy. Table 2 shows that treatment with indomethacin did not prevent the induction of $20 \alpha$-HSD by hysterectomy, and that the receptor concentration did not change when compared 
(6)

(a)

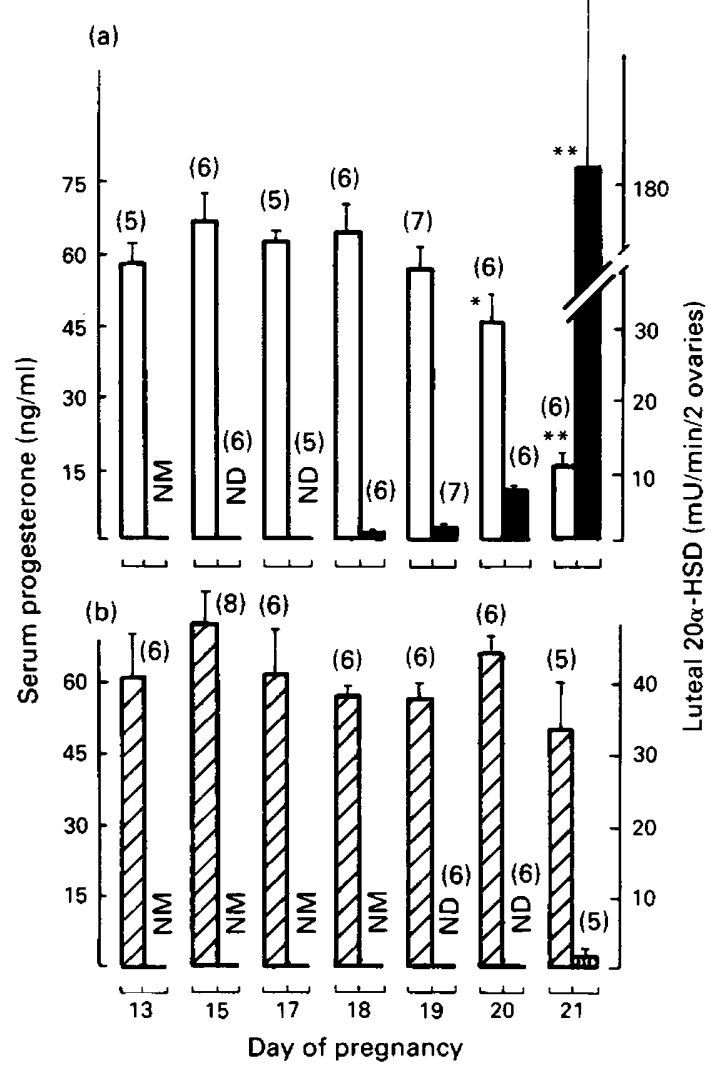

Fig. 3. Serum progesterone concentrations and ovarian 20a-HSD at various times of pregnancy in the rat. (a) Untreated pregnant rats: $\square$, serum progesterone; $\square, 20 \alpha-H S D$ activities. (b) Indomethacin-treated pregnant rats: $\mathbb{Z}$, serum progesterone; 血, 20 $\alpha$-HSD activities. Indomethacin treatment was as indicated in Fig. 2. The rats were killed at 12:00 h. Values are means \pm s.e.m. for the number of observations in parentheses. ${ }^{*} P<0.02,{ }^{* *} P<0.01$ when compared with the value of the preceding day. ND, non-detectable activities; NM, not measured.

with that of the hysterectomized, untreated rats. This was true whether the operation was performed on Day 19 of pregnancy and measurements made $24 \mathrm{~h}$ later or on Day 16 and measurements made $48 \mathrm{~h}$ later. On the other hand, hCG treatment after hysterectomy reduced the induced enzyme activity to $31 \%$ without affecting the receptor concentrations. PGF- $2 \alpha$ synthesis inhibition by indomethacin treatment to hysterectomized rats treated with hCG did not reduce further $20 \alpha-H S D$ activity nor produced changes in receptor concentrations.

The effect of hCG on enzyme induction by hysterectomy on Day 16 of pregnancy was not dependent on prolactin, since the administration of this hormone ( $1 \mathrm{mg}$ in saline s.c. every $12 \mathrm{~h}$, beginning immediately after surgery) did not increase the effect of hCG on 20a-HSD activity (hysterectomized hCG-treated $7.7 \pm 0.6 \mathrm{mU} / \mathrm{min} / 2$ ovaries, $\mathrm{N}=6$; hysterectomized $\mathrm{hCG}+$ prolactin-treated $6.1 \pm 0.5 \mathrm{mU} / \mathrm{min} / 2$ ovaries, $\mathrm{N}=8$ ). This lack of an effect of exogenous prolactin is not due to an increase of the endogenous one, which begins to increase $18-24 \mathrm{~h}$ after 
Table 1. Luteal progestagens and serum progesterone concentration in rats after PGF-2 $\alpha$ treatment

\begin{tabular}{|c|c|c|c|c|c|}
\hline & $\begin{array}{l}\text { Luteal } \\
\text { progesterone } \\
\text { (ng/100 mg) }\end{array}$ & $\begin{array}{l}\text { Luteal } \\
\text { 20 } \alpha \text {-dihydro- } \\
\text { progesterone } \\
\text { (ng/100 mg) }\end{array}$ & $\begin{array}{c}\text { 20a-OHP: } \\
\text { progesterone }\end{array}$ & $\begin{array}{c}\text { Luteal } \\
\text { progestagens } \\
(\mathrm{ng} / 100 \mathrm{mg})\end{array}$ & $\begin{array}{c}\text { Serum } \\
\text { progesterone } \\
(\mathrm{ng} / \mathrm{ml})\end{array}$ \\
\hline $\begin{array}{l}\text { Control } 2 \mathrm{~h} \\
\text { Treated } 2 \mathrm{~h} \\
\text { Treated:control }\end{array}$ & $\begin{array}{c}1528 \pm 120(5) \\
1024 \pm 73(6)^{* *} \\
0.67\end{array}$ & $\begin{array}{c}1350 \pm 221(5) \\
860 \pm 62(6)^{*} \\
0.64\end{array}$ & $\begin{array}{l}0 \cdot 88 \\
0 \cdot 84\end{array}$ & $\begin{array}{l}2878 \\
1884 \\
0.65\end{array}$ & $\begin{array}{l}69 \cdot 4 \pm 4 \cdot 4(6) \\
52 \cdot 4 \pm 5 \cdot 1(6)^{*}\end{array}$ \\
\hline $\begin{array}{l}\text { Control } 3 \mathrm{~h} \\
\text { Treated } 3 \mathrm{~h} \\
\text { Treated:control }\end{array}$ & $\begin{array}{c}1617 \pm 117(5) \\
784 \pm 61(6)^{* * *} \\
0.47\end{array}$ & $\begin{array}{c}1405 \pm 139(5) \\
1441 \pm 174(6) \\
1.03\end{array}$ & $\begin{array}{l}0.87 \\
1.84\end{array}$ & $\begin{array}{l}3022 \\
2225 \\
0.73\end{array}$ & $\begin{array}{l}70 \cdot 7 \pm 4.9(5) \\
41 \cdot 8 \pm 4.9(6)^{* *}\end{array}$ \\
\hline
\end{tabular}

Rats were injected at 10:00 h on Day 19 of pregnancy with $750 \mu \mathrm{g}$ PGF- $2 \alpha$ or vehicle and killed $2 \mathrm{~h}$ or $3 \mathrm{~h}$ later. Results are means \pm s.e.m. for the no. of rats in parentheses.

${ }^{*} P<0.05,{ }^{* *} P<0.001,{ }^{* * *} P<0.001$, compared with control value.

Table 2. PGF-2 $\alpha$ receptor concentrations and $20 \alpha-H S D$ activities in hysterectomized pregnant rats

\begin{tabular}{|c|c|c|c|c|c|}
\hline & $\begin{array}{c}\text { Day of } \\
\text { measurement }\end{array}$ & $\begin{array}{l}\text { PGF- } 2 \alpha \text { bound } \\
\quad(\mathrm{fmol} / \mathrm{mg})\end{array}$ & & $\begin{array}{c}20 \alpha-H S D \\
(\mathrm{mU} / \mathrm{min} / 2 \text { ovaries })\end{array}$ & \\
\hline Normal pregnant & 20 & $240 \pm 15(6)\}$ & \multirow{2}{*}{$P<0.05$} & $10 \cdot 8 \pm 0 \cdot 2(6)\}$ & \multirow{2}{*}{$P<0.001$} \\
\hline Hysterectomy Day 19 & 20 & $295 \pm 21(6)\}$ & & $70.3 \pm 7.9(6)\}$ & \\
\hline $\begin{array}{l}\text { Normal pregnant } \\
\text { + indomethacin }\end{array}$ & 20 & $273 \pm 10(6)$ & & ND & \\
\hline $\begin{array}{l}\text { Hysterectomy Day } 19 \\
\text { + indomethacin }\end{array}$ & 20 & $296 \pm 24(5)$ & & $69 \cdot 1 \pm 10 \cdot 7(7)$ & \\
\hline Normal pregnant & 18 & $180 \pm 13(6)\}$ & \multirow{2}{*}{$P<0.01$} & ND & \\
\hline Hysterectomy Day 16 & 18 & $289 \pm 26(6)\}$ & & $32 \cdot 9 \pm 2 \cdot 1(9)$ & \\
\hline $\begin{array}{l}\text { Normal pregnant } \\
\text { + indomethacin }\end{array}$ & 18 & $198 \pm 26(6) 7$ & \multirow{2}{*}{$P<0.01$} & ND & \multirow{4}{*}{$P<0.001$} \\
\hline $\begin{array}{l}\text { Hysterectomy Day } 16 \\
\text { +indomethacin }\end{array}$ & 18 & $328 \pm 17(6)\}$ & & $30 \cdot 2 \pm 3 \cdot 7(6)$ & \\
\hline $\begin{array}{l}\text { Hysterectomy Day } 16 \\
\text { + hCG }\end{array}$ & 18 & $266 \pm 10(6)$ & & $10 \cdot 3 \pm 0.6(9) J$ & \\
\hline $\begin{array}{l}\text { Hysterectomy Day } 16 \\
\text { +indomethacin + hCG }\end{array}$ & 18 & $288 \pm 12(6)$ & & $9.8 \pm 0.7(6)$ & \\
\hline
\end{tabular}

Indomethacin $(1 \mathrm{mg})$ was given s.c. every $12 \mathrm{~h}$ starting at $08: 00 \mathrm{~h}$ on Day 18, when surgery was performed on Day 19 and the measurement on Day 20 of pregnancy, or else on Day 15 at 20:00 h, when hysterectomy was done on Day 16 and the measurement on Day 18 of pregnancy. HCG $(1.5 \mu \mathrm{g})$ was administered every $12 \mathrm{~h}$ beginning immediately after surgery. Surgery was done between $08: 00$ and 10:00 h and the rats were killed $24 \mathrm{~h}$ (20-day groups) or $48 \mathrm{~h}$ (18 day groups) later. Results are means \pm s.e.m. for the number of observations in parentheses. ND, not detectable.

hysterectomy, inasmuch as the treatment with bromocriptine $(1.5 \mathrm{mg} / \mathrm{kg}$, every $12 \mathrm{~h}$ starting the day before surgery) did not prevent or diminish the luteotrophic effect of the hCG $(7 \cdot 6 \pm 0 \cdot 8 \mathrm{mU} /$ $\min / 2$ ovaries). 


\section{Discussion}

The observations reported here on the binding kinetics of the PGF-2 $\alpha$ to its receptor during the last stages of pregnancy are in agreement with previous reports on pseudopregnant (Wright et al., 1979, 1980) and cyclic (Muller et al., 1981) rats. A correlation was found between the luteolytic action of PGF-2 $\alpha$ and its receptor concentration in the CL. It has been reported (Strauss \& Stambaugh, 1974; Vermouth \& Deis, 1975; Rodway \& Kuhn, 1975a) that as the corpus luteum ages its sensitivity towards PGF- $2 \alpha$ increases. In agreement with these findings, the present study revealed that the concentration of binding sites reached a maximum on Day 19 of pregnancy. The subsequent decrease observed from Day 20 to 22 of pregnancy was probably due to down regulation of the receptor, since the assay measured the total amount of binding sites, and since indomethacin treatment prevented the decrease in binding normally seen at the end of pregnancy. Also, the treatment with PGF-2 $\alpha$ on Day 19 of pregnancy caused a decrease in its luteal receptor concentration.

Previous studies of pseudopregnant rats found no changes in the concentrations of the ovarian receptor on different days of pseudopregnancy (Wright et al., 1980). This is not surprising in view of the differences between the two reproductive states. The CL of pseudopregnancy are under pituitary control and, at the stage of pregnancy in which this study was done, control had already changed from the CL to the placenta (Morishige \& Rothchild, 1974).

The rise in PGF-2 $\alpha$ receptor concentration on Day 19 seems to be associated with an increase of oestrogen (Shaikh, 1971) and a decrease of serum progesterone at the end of pregnancy (Morishige et al., 1973; Bussmann \& Deis, 1979). Both steroids are known to be involved in the synthesis and metabolism of PGs in the uterus and ovary (Carminati et al., 1975). The present results of steroid treatments suggest also that, whereas progesterone does not affect the increase in PGF- $2 \alpha$ receptor, oestradiol may actually advance it, and hence make the corpus luteum more responsive to the luteolytic action of PGF-2 $\alpha$.

Although these results show that prostaglandin and its receptor are an essential part of the luteolytic process at the end of pregnancy, the fact that $20 \alpha-H S D$ induction occurs in the hysterectomized indomethacin-treated rats indicates that the induction by hysterectomy is due to the removal of luteotrophic substances arising from the uterus, as proposed earlier (Wiest et al., 1968; Rodway \& Kuhn, 1975a; Hickman-Smith \& Kuhn, 1976). In addition, no change in PGF-2 $\alpha$ receptor was found in the hysterectomized groups without indomethacin treatment, either after $20 \alpha-H S D$ induction (i.e. down regulation) or after the partial abolition of it by hCG treatment (i.e. increase in receptor concentration), indicating that prostaglandins are not involved in enzyme induction due to hysterectomy.

The increase in receptor concentration on Day 20 that follows hysterectomy is not different from that seen in indomethacin-treated unoperated rats on the same day of pregnancy. These similar values in receptor concentrations would seem to indicate that uterine rather than luteal prostaglandins cause down-regulation of receptors, at least on Day 20 of pregnancy. Also some substance arising from the uterus may be inhibiting the expression of binding sites since the values on Day 18 in hysterectomized rats were higher than those in the unoperated group.

Although there is evidence for a participation of pituitary lactogenic hormones in restraining this enzyme during early pregnancy (Rodway \& Kuhn, 1975b) and, also, a rat placental lactogen has been characterized (Shiu et al., 1973), prolactin treatment was not able in this study to enhance the luteotrophic action of hCG in rats that were hysterectomized on Day 16. Nor did the administration of bromocriptine diminish the hCG effect on these animals. The induction of $20 \alpha-H S D$ by hysterectomy, and the decrement of the induction by hCG treatment but not by indomethacin treatment, may be interpreted as suggesting that the luteolytic action of PGF- $2 \alpha$ is exerted through a blockade of the action of a placental luteotrophin with hCG-like activity; nevertheless, its molecular structure should be rather different from that of $\mathrm{LH}$, since attempts to find an mRNA encoding for the $\alpha$ - or the $\beta$-subunit of an LH/hCG-like hormone have failed (Carr \& Chin, 1985). 
The hypothesis of the abrogation of a luteotrophic stimulus is supported by the finding of a decrease in luteal binding of ${ }^{125}$ I-labelled hCG (Behrman \& Hichens, 1976) that rapidly follows the treatment in vivo with PGF- $2 \alpha$, and also by the PGF- $2 \alpha$-induced decrease in the accumulation of cAMP in luteal cells that is produced by LH, fluoride, noradrenaline or cholera toxin (Lahav et al., 1976; Khan \& Rosberg, 1979; Dorflinger \& Behrman, 1979). There is evidence that the action of PGF-2 $\alpha$ may involve changes in membrane fluidity, and a possible resulting loss of gonadotrophinbinding sites or their uncoupling from the adenylate cyclase system (Carlson et al., 1982). On the other hand lactogenic hormones seem to counteract the action of PGF-2 $\alpha$ on the luteal membrane (Behrman et al., 1978; Buhr et al., 1983).

In luteolysis preceding normal parturiton (Wiest et al., 1968), or in that caused by PGF-2 $\alpha$ (this paper), the decrease in progesterone content in the luteal cells precedes the increase of $20 \alpha$-dihydroprogesterone. This may indicate that $20 \alpha-\mathrm{HSD}$ is under the restraint of placental luteotrophic hormones (either directly, or indirectly through the maintenance of high levels of intraluteal progesterone). It is therefore suggested that luteolysis at the end of pregnancy is the result of the blockade, at the luteal cell membrane, of the luteotrophic signals coming from the placenta, i.e. placental lactogen, which has a permissive action on progesterone biosynthesis, and a molecule with hCG-like activity, which maintains the high rates of this biosynthetic pathway. The blocking of luteotrophic signals is effected by an action of PGF- $2 \alpha$ on a PGF- $2 \alpha$ membrane receptor. The decrease in intraluteal progesterone thus produced would be the signal for $20 \alpha-H S D$ induction. The increasing oestrogen concentrations at the end of pregnancy would be responsible for the crucial appearance of PGF- $2 \alpha$ binding sites in the corpora lutea and for the stimulation of PGF- $2 \alpha$ biosynthesis.

This work was supported by grants from CONICET and the BID-CONICET programme. I thank Dr A. Castro-Vazquez and Dr N. J. Kuhn for critical reading of the manuscript and Lederle Laboratories of Argentina for facilities.

\section{References}

Behrman, H.R. \& Hichens, M. (1976) Rapid block of gonadotropin uptake by corpora lutea in vivo induced by prostaglandin F-2 $\alpha$. Prostaglandins 12, 83-95.

Behrman, H.R., Grinwich, D.L., Hichens, M. \& Macdonald, G.J. (1978) Effect of hypophysectomy, prolactin and prostaglandin $\mathrm{F}-2 \alpha$ on gonadotropin binding in vivo and in vitro in the corpora lutea. Endocrinology 103, 349-357.

Behrman, H.R., Luborsky-Moore, S.L., Pang, C.Y., Wright, K. \& Dorflinger, L.J. (1979) Mechanism of PGF- $2 \alpha$ action in functional luteolysis. In Ovarian Follicular and Corpus Luteum Function, pp. 557-571. Eds C. P. Channing, J. Marsh \& W. A. Sadler. Plenum Press, New York.

Blank, M.S., Dufau, M.L. \& Friesen, H.G. (1979) Demonstration of a potent, gonadotropin-like biological activity in the serum of rats during midpregnancy. Life Sci. 25, 1023-1028.

Buhr, M.M., Gruber, M.Y., Ryley, J.C.M. \& Carlson, J.C. (1983) The effect of prolactin pre-treatment on prostaglandin $\mathrm{F}_{2} \alpha$-associated structural change in membrane on rat corpora lutea. Am. J. Obstet. Gynecol. 145, 263-268.

Bussmann, L. \& Deis, R. (1979) Studies concerning the hormonal induction of lactogenesis by prostaglandin F-2 $\alpha$ in the pregnant rat. J. Steroid Biochem. 11, $1485-1489$.
Carlson, J.C., Buhr, M.M., Wentworth, R. \& Hansel, W. (1982) Evidence of membrane change during regression in the bovine corpus luteum. Endocrinology 110, 1472-1476.

Carminati, P., Luzzani, F., Soffietini, A. \& Lerner, L.J. (1975) Influence of day of pregnancy on rat placental, uterine and ovarian prostaglandin synthesis and metabolism. Endocrinology 97, 1071-1079.

Carr, F. \& Chin, W. (1985) Absence of detectable chorionic gonadotrophin subunit messenger ribonucleic acids in the rat placenta throughout gestation. Endocrinology 116, 1151-1157.

Dorflinger, L.J. \& Behrman, H.R. (1979) Effects of cholera toxin, LH and PGF-2 $\alpha$ on steroidogenesis in luteal cells. In Ovarian Follicular and Corpus Luteum Function, pp. 603-608. Eds C. P. Channing, J. Marsh \& W. A. Sadler. Plenum Press, New York.

Hickman-Smith, D. \& Kuhn, N.J. (1976) A proposed sequence of hormones controlling the induction of luteal $20 \alpha$-hydroxysteroid dehydrogenase and progesterone withdrawal in the late pregnant rat. Biochem. $J$. 160, 663-670.

Khan, M.I. \& Rosberg, S. (1979) Acute suppression by PGF $2 \alpha$ on $\mathrm{LH}$, epinephrine and fluoride stimulation of adenylate cyclase in rat luteal tissue. $J$. cyclic $\mathrm{Nucl}$. Res. 5, 55-63. 
Kuhn, N.J. \& Briley, M.S. (1970) The roles of preg-5-ene$3 \beta, 20 \alpha$-diol and $20 \alpha$-hydroxysteroid dehydrogenase in the control of progesterone synthesis preceding parturition and lactogenesis in the rat. Biochem. $J$. 117, 193-201.

Lahav, M., Freud, A. \& Lindner, H.R. (1976) Abrogation by prostaglandin F- $2 \alpha$ of $\mathrm{LH}$-stimulated cyclic AMP accumulation in isolated rat corpora lutea post pregnancy. Biochem. Biophys. Res. Commun. 68, $1294-1300$.

Lowry, O.H., Rosebrough, N.J., Farr, A.L. \& Randall, R.J. (1951) Protein measurement with the Folin phenol reagent. J. biol. Chem. 193, 265-276.

Morishige, W.K. \& Rothchild, I. (1974) Temporal aspects of the regulation of corpus luteum function by luteinizing hormone, prolactin and placental luteotrophin during the first half of pregnancy in the rat. Endocrinology 95, 260-274.

Morishige, W.K., Pepe, G.J. \& Rothchild, I. (1973) Serum luteinizing hormone, prolactin and progesterone levels during pregnancy in the rat. Endocrinology 92, 1527-1529.

Muller, U., Bauknecht, Th. \& Siebers, J.W. (1981) Development and regulation of the prostaglandin $F_{2 a}$ receptor in the rat ovary. Acta endocr., Copenh. $\mathbf{9 8}$, 441-445.

Pharriss, B.B. \& Wyngarden, L.J. (1969) The effect of PGF-2 $\alpha$ on the progestogen content of ovaries from pseudopregnant rats. Proc. Soc. exp. Biol. Med. 130 , 92-94.

Rao, Ch.V. (1975) The presence of discrete receptors for prostaglandin F-2 $\alpha$ in the cell membranes of bovine corpora lutea. Biochem. Biophys. Res. Commun. 64, $416-424$.

Rodway, R.G. \& Kuhn, N.J. (1975a) Hormonal control of luteal $20 \alpha$-hydroxysteroid dehydrogenase and $\Delta^{5}$. $3 \beta$ hydroxysteroid dehydrogenase during luteolysis in the pregnant rat. Biochem. J. 152, 433-443.

Rodway, R.G. \& Kuhn, N.J. (1975b) Luteal 20ahydroxysteroid dehydrogenase and the formation of
$\Delta^{4}$-3-oxosteroids in the rat after weaning or treatment with 2-bromo-a-ergocryptine during lactation. Biochem. J. 152, 445448.

Scatchard, G. (1949) The attractions of proteins for small molecules and ions. Ann. N.Y. Acad. Sci. 51, 660-672.

Schrader, W.T. (1975) Methods for extraction and quantification of receptors. In Methods in Enzymology, vol. 26, pp. 196-198. Eds B. O. O'Malley \& J. G. Hardman. Academic Press, New York.

Shaikh, A.A. (1971) Estrone and estradiol levels in the ovarian venous blood from rats during cycle and pregnancy. Biol. Reprod. 5, 297-307.

Shiu, R.P.C., Kelly, P.A. \& Friesen, H.G. (1973) Radioreceptor assay for prolactin and other lactogenic hormones. Science, N.Y. 180, 968-971.

Strauss, J.F. \& Stambaugh, R.L. (1974) Induction of $20 \alpha-$ hydroxysteroid dehydrogenase in rat corpora lutea of pregnancy by prostaglandin F-2 $\alpha$. Prostaglandins 5, 73-85.

Thorell, J.I. \& Johansson, B.J. (1971) Enzymatic iodination of polypeptides with ${ }^{125}$ I to high specific activity. Biochim. biophys. Acta 251, 363-369.

Vermouth, N.T. \& Deis, R. (1975) Inhibitory effect of progesterone on the lactogenic and abortive action of prostaglandin F-2 $\alpha$. J. Endocr. 66, 21-29.

Wiest, W.G., Kidwell, W.A. \& Balogh, K. (1968) Progesterone catabolism in the rat ovary: a regulatory mechanism for progesterone potency during pregnancy. Endocrinology 82, 844-859.

Wright, K., Luborsky-Moore, S.L. \& Behrman, H.R. (1979) Specific binding of prostaglandin F-2 $\alpha$ to membranes of rat corpora lutea. Molec. cell. Endocrinol. 13, 25-34.

Wright, K., Pang, C.Y. \& Behrman, H.R. (1980) Luteal membrane binding of prostaglandin F-2 $\alpha$ induced luteolysis in pseudopregnant rats. Endocrinology 106, 1333-1337.

Received 25 November 1987 